\title{
The Mediating Role of Hope and Loneliness in the Relationship Between Meaningful Life and Psychological Resilience in the Covid-19 Pandemic During

\author{
Covid-19 Salgın Sürecinde Anlamlı Yaşam ve Yılmazlık Arasındaki İlişkide Umut ve \\ Yalnızlı̆̆ın Aracı Rolü
}

\author{
Hasan Batmaz*, Caner Doğrusever**, Nuri Türk ${ }^{* * *}$
}

\begin{abstract}
The pandemic has also revealed the quarantine processes. Individuals have experienced many psychological disorders in this process. Therefore, individuals' psychological resilience and loneliness are also aaffected. As a result, individuals have made an effort to seek ways of meaningful life and hope in this life. In this study, the effects of hope and loneliness levels on meaningful life and resilience were examined.In this study, the mediating role of hope and loneliness in the relationship between the meaningful life levels of university students and their psychological resilience was examined. The study was carried out on a total of 307 university students, 208 (68\%) female and 99 (32\%) male. Easy-to-reach sampling method was used in the study. According to the results of the research, there were negative correlations between loneliness and hope, meaningful life, and resilience; There were positive correlations between hQ ope and meaningful life and resilience, and positive significant relationships between resilience and meaningful life. Bootstrapping results showed that hope and loneliness partially mediated the relationship between meaningful life and psychological resilience. As a result, the relationship between meaningful life and resilience becomes meaningful with the effect of hope and loneliness levels.
\end{abstract}

Keywords: Covid-19, Meaningful Life, Psychological Resilience, Hope, Loneliness

Öz: Pandemi, beraberinde karantina süreçlerini de ortaya çıkarmıştır. Bireyler bu süreçte psikolojik yönden birçok rahatsızlık yaşamıştır. Bu nedenle bireylerin psikolojik yılmazlı̆̆ ve yalnızlı̆ğ da bu durumdan etkilenmektedir. Bireyler bu hayatta anlamlı yaşam ve umudun yollarını aramak için çaba sarf etmişlerdir. Bu çalışmada umut ve yalnızlık düzeylerinin anlamlı yaşam ve yılmazlık üzerindeki etkisi incelenmiştir. Bu çalışmada üniversite öğrencilerinin anlamlı yaşam düzeyleri ile yılmazlık arasındaki ilişkide umudun ve yalnızlığın aracı rolü incelenmiştir. Çalışma 208'i (\%68) kız, 99'u (\%32) erkek olmak üzere toplam 307 üniversite öğrencisi üzerinde gerçekleştirilmiştir. Araştırmada ulaşılması kolay örnekleme yöntemi kullanılmıştır. Araştırma sonuçlarına göre yalnızlık ile umut, anlamlı yaşam, yılmazlık arasında negatif; umut ile anlamlı yaşam ve yılmazlık arasında pozitif ve yılmazlık ile anlamlı yaşam arasında pozitif yönde anlamlı ilişkiler tespit edilmiştir. Bootstrapping sonuçları, umut ve yalnızlı̆̆ın anlamlı yaşam ile yılmazlık arasındaki ilişkide kısmi aracılık etkisi olduğunu göstermiştir.

\footnotetext{
* Doktora Öğrencisi, Sakarya Üniversitesi, Eğitim Bilimleri Enstitüsü, Rehberlik ve Psikolojik Danışmanlık ORCID: 0000-0002-5979-1586, hasanbatmaz1992@gmail.com (sorumlu yazar)

${ }^{* *}$ Dr.Öğr.Üyesi, Siirt Üniversitesi, Eğitim Fakültesi, Rehberlik ve Psikolojik Danışmanlık ORCID: 0000-0002-2213-4021, caner.dsever@hotmail.com

${ }^{* * * *}$ Arş.Gör. Siirt Üniversitesi, Eğitim Fakültesi, Rehberlik ve Psikolojik Danışmanlık

ORCID: 0000-0002-7059-,nuriturk60@gmail.com

Received/Geliş: 11 March/Mart 2021

Accepted/Kabul: 27 July/Temmuz 2021

Düzeltme/Revised form: $20 \mathrm{July} / \mathrm{Temmuz} 2021$

Published/Yayın: 25 October/Ekim 2021
}

e-ISSN: 2149-4622. @ 2013-2021 Muş Alparslan Üniversitesi. TÜBİTAK ULAKBİM DergiPark ev sahipliğinde. Her hakkı saklıdır. http://dx.doi.org/10.18506/anemon.895199 
Sonuç olarak anlamlı yaşam ile yılmazlık arasındaki ilişki umut ve yalnızlık düzeylerinin de etkisiyle anlamlı hale gelmektedir.

Anahtar Kelimeler: Covid-19, Anlamlı Yaşam, Yılmazlık, Yalnızlık, Umut

\section{Introduction}

Epidemics that have affected the whole world throughout history have had negative effects on people in many cognitive, emotional and behavioral areas. In researchs that on SARS (Severe Acute Respiratory Syndrome) outbreak as in Ebola (Lau et al., 2016) and MERS (Lee et al., 2018) virus (Cai et al., 2020; Huang and Zhao, 2020) stress levels increased during the epidemic processes and depressive disorders increased after the outbreak. Today, the Covid-19 pandemic has been normaling all normals since December 2019, pushing humanity into economic, medical, educational, family and social problems (Akat and Karatas, 2020; Tanhan et al., 2020). In addition to all these problems, the fact that the pandemic since it began, the deaths and quarantines applied increase the continuity of stress and fear (Mertens et al., 2020; Naeem, Irfan and Javed, 2020; Yildirim and Arslan, 2020) and has been caused psychological problems such as anxiety and depression (Ahorsu et al., 2020; Fardin, 2020; Qui et al., 2020; Stankovska ark., 2020).

Although the pandemic affects people of all age groups, it has been caused more various problems for students who start to take distance education compulsorily during the epidemic process. Even if it is known that university students experienced academic, economic, family and personal problems before the pandemic (Aktaş,1997; Aydin and Egemberdiyeva, 2018; Erkan et al., 2012) with the pandemic, this problems are aggravated. How students respond to the problems they are going through is associated with levels of psychological resilience (Arden and Chilcot, 2020; Kluge, 2020). Psychological resilience is the ability to withstand one's problems (Gizir, 2007; Jackson et al., 2007), the ability to successfully overcome adverse situations such as stress (Karairmak, 2016; Korkut-Owen et al., 2017) being able the ability to recover and return to life and the ability to adapt to new situations (Dogan, 2015; Smith et al., 2008; Tusaie and Dyer, 2004). Psychological resilience consists of two components: risk and protective factors. Risk factors decrease psychological resilience, while protective factors increase (Karal and Biçer, 2020). Research shows that the Covid-19 pandemic is a risk factor that threatens psychological resilience (Bozdag, 2020; Wang et al., 2020). The high psychological resilience, in addition to being supportive in difficult living conditions (Öz \& Bahadır Yılmaz, 2009), reduces the level of anxiety (Artan, Atak, Karaman, \& Cebeci, 2020), the negative consequences of the Covid-19 outbreak (Bilge \& Bilge, 2020; Lin and others, 2020).In addition to affecting the psychological resilience of individuals, the Covid-19 pandemic can also lead them to more loneliness. Loneliness,inconsistency between desirable and perceived social relationships (Blazer, 2002; Jeste, Lee and Cacioppo, 2020) is expressed with different definitions, such as experience in the event of loss of quantity and qu ality of social and emotional networks (Peplau and Perlman, 1982).In studies conducted before the Covid-19 pandemic, it is known that loneliness is gradually increasing in the world and is beginning to be seen as a health problem (Berguno et al., 2004: Gardiner et al., 2020; Holt-Lunstad, 2017). It has been concluded that their practices lead individuals to loneliness and negatively affect their mental health (Killgore et al., 2020; Li \& Wang, 2020). In cases of loneliness after various disasters andand traumas, broad social networks and social support appear to be decisive in increasing psychological resilience (American Psychological Association, 2020; Bu, Steptoe and Fancourt, 2020). Loneliness appears to be an important variable in understanding the psychological consequences of the Covid-19 pandemic and being able to create and deal with protective factors (Holmes et al., 2020).

Another concept that needs to be addressed together with loneliness in the Covid-19 pandemic is hope. The hope is the capacity (Snyder, 2000) to identify the paths to the goal and achieve the conclusion they want, and the psychological strength that strengthens resistance and helps deal with ailments (Fredrickson, Tugade, Waugh and Larkin, 2003; Schwarzer and Luszczynska, 2008). Hope is a psychological resource that also allows you to more accept crisis situations and psychological problems (Miller-Smedema et al., 2010). Deaths in the Covid-19 pandemic, severe illnesses, loss of dreams, uncertain tomorrows, educational and financial difficulties increased despair (Killgore et al., 2020; Walsh, 2020). Realistic hope is needed to replace despair with what is possible and to reconcile with 
what cannot be changed (Walsh, 2020; Weingarten, 2010). As research has proven that hope positively affects psychological health (DuBois et al., 2015; Glass et al. 2009; Rawdin et al. 2013; Waynor et al., 2012) also plays a functional role in supporting psychological well-being of individuals in the fight against the epidemic (Counted et al., 2020; Satici et al., 2020; Yildirim and Arslan, 2020).

In addition to loneliness and hope, another concept that is the subject of our research is meaningful life. Meaningful life is a subjective concept that includes several key components such as success, love and inevitable anguish (Frankl, 1985). The concept of meaningful life is the main motivator of the individual in an existential approach (Sharf, 2012). According to Frankl (1985), people's search for meaning in life varies and those with purpose in life they can live much longer in difficult processes (disease, war, etc.) than those who have no meaning and purpose in life. For this reason, it is seen that people who have important goals in their lives perceive their lives as more meaningful (Emmos, 2005). Research has highlighted that the meaning in life is important for various mental health indicators such as social and physical functionality, subjective well-being, hope for psychological well-being, depression, social support and anxiety (Kleftaras and Psarra, 2012; Lin, 2020; Mascaro and Rosen, 2005; Minkkinen et al., 2020). All however limited, meaning in life was also found to be associated with emotional well-being (Garrosa-Hernández et al., 2013). In a study, it was emphasized that lack of meaning in one's life can cause psychopathology and psychological disorders (Maccallum and Bryant, 2019). In a study, Arslan and Allen (2020) reported that the meaning in life is an important enemy of life insatiable and mediates the negative impact of coronavirus stress on psychological well-being. Other research on this subject has also revealed that meaning in life positively and meaningfully exhausts positive mental health, including emotional well-being, social well-being, and psychological well-being (Arslan et al., 2020; García-Alandete, Martínez, Sellés Nohales and Soucase Lozano, 2018).

When the literature is examined, the psychological resilience of individuals (Bozdağ, 2020; Wang et al., 2020) is affected by hope for the future (Killgore et al., 2020; Walsh, 2020), meaningful life (Arslan \& Allen, 2020) and loneliness (Killgore et al., 2020; Li and Wang, 2020). Therefore, it is understood that it is important to investigate the predictor effects of loneliness, hope and meaningful life variables in order to reduce the negative effects of the pandemic process and increase the psychological resilience of individuals. In addition, related to the concept of hope until today (Counted et al., 2020; Karairmak 2007; Kumpfer, 1999; Ong, Edwards and Bergeman, 2006; Satici et al., 2020; Snyder, 2000; Yildirim and Arslan, 2020) and loneliness (Altundag, 2013; Cetin and Anuk, 2020; Guloglu and Karairmak, 2010; Rew, Taylor-Seehafer, Thomas and Yockey, 2001) with psychological resilience, and meaningful life with psychological health (Yildirim, Arslan and Wong, 2020) and positive mental health (Arslan et al., 2020; García-Alandete et al., 2018) works have been done. As a result, considering the relationships between psychological resilience, loneliness, hope and meaningful life, it is thought that hope and meaningful life can be mediating variables between loneliness and psychological resilience.

When the literature is examined, the trends and status of the studies conducted in our country show hope, academic self-efficacy and problem solving levels (Atik \& Atik, 2017), problem solving, hope and self-efficacy (Çam et al., 2020), gratitude, hope, optimism and life, satisfaction as predictors of psychological well-being (Kardaş et al., 2019), anxiety and spirituality during the covid-19 epidemic, psychological resilience and intolerance to uncertainty (Kasapoğlu, 2020), levels of piety and hope of university students (Dağc1, 2020), religiosity and death anxiety relationship (Kandemir, 2020) and the meaning of life and religiosity (Karş1, 2020). However, the lack of a study addressing meaningful life, psychological resilience, hope and loneliness levels in the covid-19 process and the individuals' experiences related to these concepts during the epidemic process distinguishes the research from the others. As a matter of fact, it is thought that a phenomenon such as an epidemic that has a significant impact on the social level may affect the psychological resilience and loneliness levels of individuals. İsolation periods throughout the country push individuals to more loneliness and provide the opportunity to search for what meaningful life is in this loneliness process, revealing its difference from other studies.

When examined in the literature, there was no research addressing the mediating roles of hope and loneliness in the relationship between meaningful life and psychological resilience before and after 
the Covid-19 pandemic. The aim of this research is to examine the relationships between meaningful life, psychological resilience, hope and loneliness during the Covid 19 pandemic, as well as the mediating roles of hope and loneliness between meaningful life and psychological resilience. For this purpose, the research hypotheses are listed below:

1.There is a significant relationship between meaningful life and psychological resilience

2.There is a significant relationship between meaningful life and hope.

3.There is a significant relationship between meaningful life and loneliness.

4.In the relationship between meaningful life and psychological resilience hope has a mediating role.

5.There is a mediating role of loneliness in the relationship between meaningful life and psychological resilience.

\section{Method}

\section{Research design}

This research, which deals with the mediating roles of hope and loneliness in the relationship between the meaning of life and psychological resilience in university students during the Covid 19 process, is a descriptive research with a correlational survey model from quantitative methods.

\section{Study group}

The study group of the research is a total of 307 [Agerange=17-49, Agemean=22.85, AgeSD= 3.60] university students, including 208 (68\%) women and 99 (32\%) men, who studied in different departments at Karabuk University, Siirt University, Ataturk University and Agri Ibrahim Cecen University in Turkey during the 2020-2021 academic year. The study group is based on "easily accessible status sampling" from purpose sampling methods. The ethics committee approval of the research was obtained with the session number 25, dated 01.02.2021 of Siirt University.

\section{Measurement tools}

The data were collected using the Brief Resilience Scale, Dispositional Hope Scale, Meaningful Living Measure, UCLA Loneliness Scale.

\section{Brief psychological resilience scale}

It was developed by Smith and his friends (2008) to measure the psychological resilience of individuals. The scale adapted to Turkish by Dogan (2015) is a 5-likert type measuring tool consisting of 6 substances. The 'I don't agree at all' option on the scale is 1, and the 'I totally agree' option is scored at 5. A high score from the scale shows high psychological resilience. In Doğan's (2015) study, the Cronbach's alpha internal consistency coefficient of the scale was calculated as .83. The findings showed that scale is a valid and reliable measuring tool that can be used in Turkish culture. In this study, the Cronbach's alpha internal consistency coefficient was calculated as .77.

\section{Dispositional hope scale}

Dispositional Hope Scale (SUÖ), developed by Snyder et al. (1991), consists of 12 items and two sub-dimensions. Each of the sub-dimensions of Actuating Thinking and Alternative Ways Thinking is measured with four items. The other four items consist of fillers that have nothing to do with hope. Items on the scale are marked with a Likert type octa-eight rating (1: Absolutely False, 8: Absolutely True). While the scale is scored, fillers are not given points, and the points obtained from the Sub-dimensions of Alternative Ways Thinking and Actuating Thinking are collected and the total score of SUÖ is obtained. The lowest score from the scale is 8 and the highest score is 64. The Turkish adaptation of the scale was carried out by Tarhan and Bacanl1 (2015). Fit index values as the result of Confirmatory Factor Analysis were found $\mathrm{GFI}=.96, \mathrm{AGFI}=.92, \mathrm{RMR}=.08, \mathrm{NNFI}=.94, \mathrm{RFI}=.90, \mathrm{CFI}=.96$ and $\mathrm{RMSEA}$ $=.077$. The Cronbach's alpha internal consistency coefficient of the scale was calculated as .83 for the total score. The findings showed that scale is a valid and reliable measuring tool that can be used in 
Turkish culture. In this study, the Cronbach alpha internal consistency coefficient was calculated as .61 over the total score of the scale.

\section{Meaningful living measure}

The scale was developed by Arslan (2020). The scale is a one-dimensional 7-point Likert-type scale consisting of 6 items. The reliability study of the scale was conducted on the latent structure reliability and internal consistency coefficient values.The scale revealed strong internal consistency values in both study groups, and it was observed that the scale also had a strong latent construct reliability. Reliability analysis results, Cronbach alpha internal consistency value of the scale was calculated as .83 for the first sample and .80 for the second sample. In addition, the scale was also found to have a strong latent construct reliability $(\mathrm{H}=.83)$. Regarding the results of the confirmatory factor analysis of the scale, when the fit values were examined, it was seen that the CFI value was .99, the TLI value was .98 , the SRMR and RMSEA values were .030 and .051 (RMSEA $90 \% \mathrm{CI}=.00, .10$ ). These results showed that the measurement model produced strong fit values. In this study, the Cronbach alpha internal consistency coefficient was calculated as .83 over the total score of the scale.

\section{UCLA Loneliness scale short form}

It was developed by Russell, Peplau and Ferguson (1978) in order to determine the degree of loneliness perceived by the individual. The UCLA Loneliness Scale, adapted to Turkish by Demir (1989), is a four-point Likert-type scale consisting of 20 items, 10 of which are straight and 10 are reverse coded. The UCLA Loneliness Scale short form (UCLA-KF) was developed by Hays and DiMatteo (1987), consisting of 8 items, including 2 inverse items (items 3 and 6), and 6 items straight, as a result of the study conducted with 199 university students. Converted to short form by Hays and DiMatteo (1987), UCLA-KF's validity and confidence studies were conducted with adolescents and college students. As a result of the confidence study, the Cronbach alpha coefficient of the scale was found to be .84. The Ucla Loneliness Scale Short Form is adapted for Turkish by Yildiz and Duy (2014). The Cronbach alpha internal consistency coefficient of the Turkish form of the scale was determined as .84. In this study, the Cronbach alpha internal consistency coefficient was calculated as .85.

\section{Data collection process}

The data was collected online via google forms from students from four different public universities who volunteered to participate in the research in January 2021. During the data collection phase, information was provided in the explanation part of the form about the purpose of using the data collected within the scope of the research, the right to withdraw, privacy and content. The response time of the scales lasts from about 10 to 15 minutes. All transactions in the data collection process have been approved by the Ethics Committee of Siirt University. A total of 307 university students who continued to different faculties of universities were reached during the data collection process. Before the data is analyzed, a total of 8 data forms that leave some scales blank without filling in, mark multiple scale items, or have deficiencies in the personal information form are not included in the analysis.

\section{Data analysis}

In this research, descriptive analyzes, correlation analyzes and structural equation modeling calculations were made using Mplus Editor 8. In this study, which was carried out to determine the network of relationships between the meaning of life, resilience, loneliness and hope in university students, first of all, descriptive statistics of the variables, the relationships between the variables and the multivariate normal distribution were tested. Afterwards, two-stage Structural Equation Modeling (SEM) was carried out in line with the recommendations of Anderson and Gerbing (1988) and Kline (2015). In the first stage, the measurement model was tested. After the measurement model results were within acceptable threshold limits, it was started to test the hypothetically constructed structural equation model using the weighted least squares mean and variance adjusted (WLSMV) estimator. Meaning of life is one latent variable, six observed variables; loneliness one latent variable, seven observed variables; hope was included in the model as one latent variable, eight observed variables, and resilience as one latent variable and six observed variables. 
In order to fully reveal the network of relationships, both the partial mediation and the fully mediation model were tested. A number of goodness-of-fit indices were used to test whether the tested models were validated. These are CFI, TLI and RMSEA values. As an acceptable critical threshold; CFI and TLI > 0.90; RMSEA was determined as < .10 (Hu and Bentler 1999; Tabachnick and Fidell, 2001). In model comparisons (partial, full), whether the goodness-of-fit indices are within acceptable limits and the model that best meets the threshold values was taken into account.

Mediation analyzes were carried out in line with the recommendations of Preacher and Hayes (2008). The bootstrapping procedure was used to examine the significance of indirect effects (Preacher $\&$ Hayes, 2008). The bootstrapping procedure is a method used to repeatedly extract samples from the data set and estimate the indirect effect on each resampled data set (Preacher \& Hayes, 2008). Hayes (2013) states that in order to decide whether the indirect effect is significant, the lower and upper bounds of the confidence interval should not cover zero, and the confidence interval covering zero indicates a non-significant effect. The bootstrapping procedure allows for a $95 \%$ confidence interval for the effect size of the indirect effect. In this study, the bootstrap coefficient and confidence intervals were calculated by making 1000 bootstraps (resampling).

\section{Results}

\section{Descriptive Statistics and Correlation Analysis Results}

Spearman's rank correlation coefficient and descriptive statistics were calculated to determine the relationship between loneliness, hope, meaningful life and psychological resilience. Results are presented in Table 1.

Table 1. Correlation Values and Descriptive Statistics Between Variables

\begin{tabular}{lcccc}
\hline Variables & 1 & 2 & 3 & 4 \\
\hline 1. Loneliness & 1 & & & \\
2. Hope & $-.52^{* *}$ & 1 & & \\
3. Meaningful Life & $-.59^{* *}$ & $.80^{* *}$ & 1 & \\
4. Psychological Resilience & $-.47^{* *}$ & $.53^{* *}$ & $.45^{* *}$ & 1 \\
\hline Mean & 12.43 & 49.44 & 34.58 & 18.04 \\
SD & 4.67 & 9.41 & 6.61 & 4.65 \\
Minimum & 7 & 8 & 6 & 6 \\
Maximum & 28 & 64 & 42 & 30 \\
\hline$* *$ p $<.001$ & & & &
\end{tabular}

There is a significant negative relationship between loneliness and other variables of research: hope $(\mathrm{r}=-.52, \mathrm{p}<.001)$, meaning of life $(\mathrm{r}=-.59, \mathrm{p}<.001)$, and psychological resilience $(\mathrm{r}=-.47, \mathrm{p}<.001)$. Positively significant relationships were found between hope and the meaning of life $(r=.80, p<.001)$ and psychological resilience $(\mathrm{r}=.53, \mathrm{p}<.001)$. Finally, it was found that there was a positively significant relationship between the meaning of life and psychological resilience $(r=.45, p<.001)$.

\section{Multivariate Normality}

If the data has a multivariate normal distribution, it means that every variable in the data has a univariate normal distribution and every pair of variables has a bivariate normal distribution (Hayduk, 1987 cited in Wang, 2012). When the multivariate normal distribution test results of the variables used in the study were examined, the multivariate skewness $(\mathrm{p}=0.00)$ and kurtosis $(\mathrm{p}=0.00)$ test results were found to be significant $(\mathrm{p}<.05)$. This result showed that the multivariate normality hypothesis was not met. Therefore, when the data do not meet the multiple normality assumption, also the indicator variables of the scales used in the research were in an ordered-categorical structure, the structural equation modeling was carried out using the WLSMV estimator (Kline, 2015). 


\section{Measurement Model}

In the study, firstly, the measurement model was tested in order to evaluate whether each of the latent variables is represented by the observed variables. In short, the measurement model is that all measurement tools (latent variables and indicator variables) used in the research are subjected to confirmatory factor analysis at the same time. The latent variables and the indicator variables that make up these variables are associated using arrows, and in the measurement model, the relationships between all the variables used in the research are looked at the same time. The measurement model consists of four latent variables (meaning of life, loneliness, hope, and resilience) and twenty-eight indicators. The measurement model test results showed acceptable model fit values: CFI = .90; TLI = .90; SRMR=.07; RMSEA $=.079$ C.I. $[.042, .071]$. Factor loads of all indicators were significant (between .51 and .90 , $\mathrm{p}<.001)$. This result shows that the indicators are the true representatives of latent factors.

\section{Structural Equation Modeling}

A series of structural models were tested to test the effectiveness of the hypothetical model. We first looked at partially mediation (Model 1). In this model, loneliness and hope were included as mediator, and a direct path was drawn between the meaning of life and resilience. Although Model 1 gave acceptable model fit values $(\mathrm{CFI}=.91 ; \mathrm{TLI}=.90 ; \mathrm{SRMR}=.07$; RMSEA $=.078)$, the path from meaning of life to resilience was not significant $(\beta=-.13, p>.05)$. After Model 1, a nonsignificant path from meaning of life to resilience removed from the model and fully mediation model (Model 2) was tested. In this model, loneliness and hope were included as mediator, and the direct path between the meaning of life and resilience was removed. Model 2 gave acceptable model fit values $(\mathrm{CFI}=.91$; $\mathrm{TLI}=.90 ;$ SRMR $=.07 ; \mathrm{RMSEA}=.078)$ and all path coefficients were significant. In conclusion, the meaning of life has significant indirect effects on resilience through loneliness and hope (Figure 1).

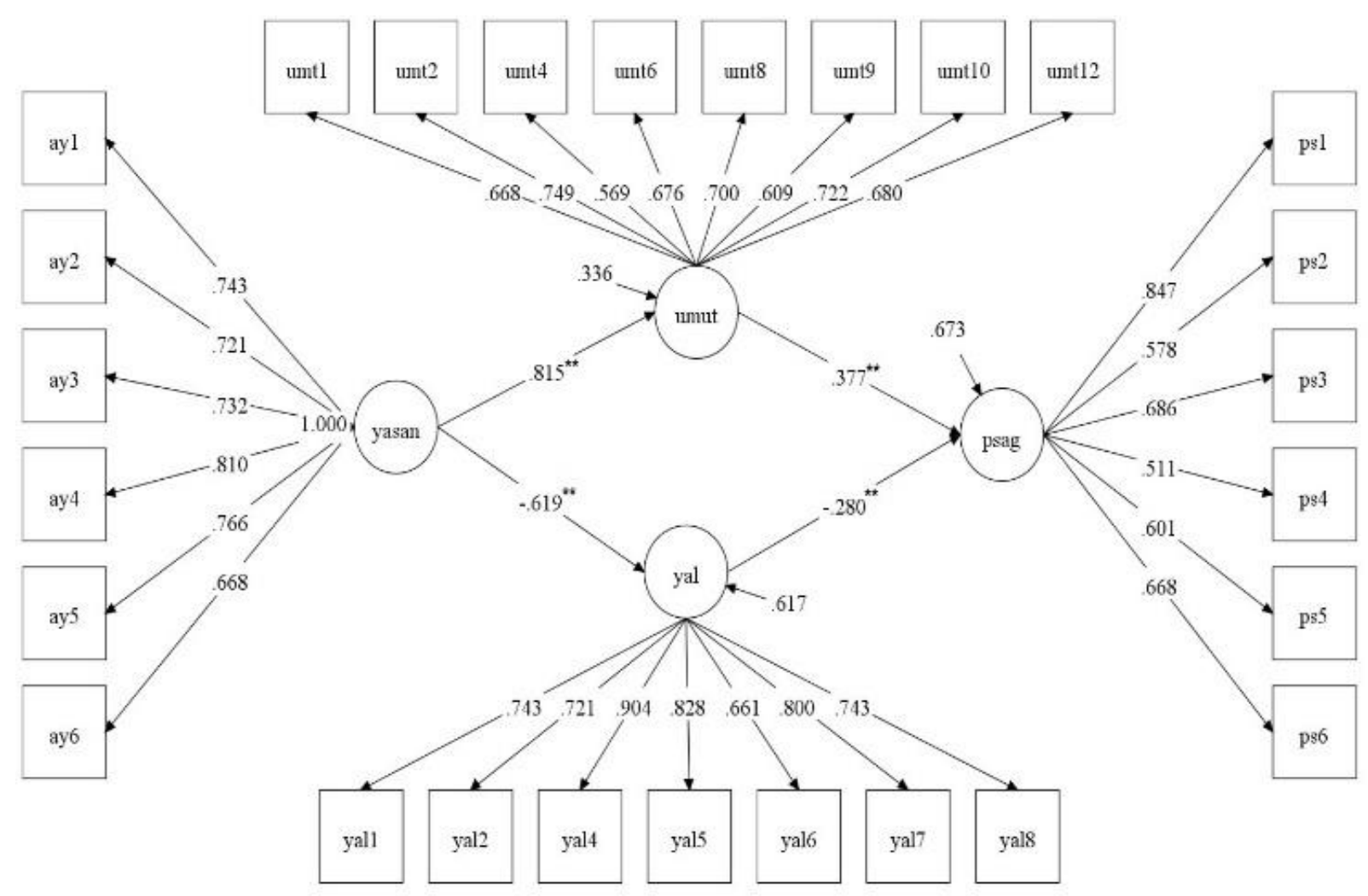

Figure 1. Standardized factor loads for the fully mediated structural model. Note: $\mathrm{N}=307,{ }^{*} \mathrm{p}<.001$; yasan, the meaning of life; yal, loneliness; umut, hope; psag, resilience. 


\section{Bootstrapping Process}

The full mediator role of hope and loneliness in the relationship between the meaning of life and psychological resilience in university students during the Covid 19 process was tested using the bootstrapping process. The coefficients for the direct and indirect effects resulting from this process and the confidence intervals for these coefficients are presented in Table 2.

Table 2. Bootstrapping Process of the Fully Mediation Model

\begin{tabular}{lccc}
\hline & & \multicolumn{2}{c}{$\% 95 \mathrm{CI}$} \\
\cline { 2 - 4 } Model Paths & Coeff. & $\begin{array}{l}\text { Lower } \\
\text { Bound }\end{array}$ & Upper Bound \\
\hline Direct effects & & & \\
Meaning of life-Hope & .815 & .743 & .875 \\
Meaning of life- Loneliness & -.619 & -.702 & -.524 \\
Hope - Resilience & .377 & .242 & .501 \\
Loneliness - Resilience & -.280 & -.416 & -.144 \\
\hline Indirect effects & & & .416 \\
Meaning of life - Hope -Resilience & .307 & .192 & .270 \\
Meaning of life- Loneliness - Resilience & .173 & .082 & \\
\hline Coeff. : Coefficient & & & \\
\hline
\end{tabular}

When the bootstrapping coefficients presented in Table 2 and the confidence intervals of these coefficients are examined, it is seen that the direct and indirect paths are significant. In addition, it is understood that both hope (bootstrap coefficient $=.30,95 \% \mathrm{CI}=.19, .41$ ) and loneliness (bootstrap coefficient $=.17,95 \% \mathrm{CI}=.08, .27$ ) are significant mediating variables between the meaning of life and resilience. Considering all these results, it can be said that hope and loneliness play a fully mediating role between the meaning of life and psychological resilience.

\section{Conclusion and Discussion}

The aim of this study examines the role of hope and loneliness in the relationship between meaningful life and psychological resilience in the Covid-19 pandemic process. The Covid 19 pandemic has primarily caused individuals to question the meaning of life and increased their loneliness levels with quarantine processes. However, individuals have entered into expectations for a more peaceful and healthy life in the future. Since the expectations for the future are hopeful, a high level of psychological resilience emerged as a desirable situation. In particular, psychological resilience has a functional role to play in deal with Covid 19 (Arden and Chilcot, 2020; Kluge, 2020) and it is understood that it is necessary to investigate predictor variables in increasing psychological resilience. In this study conducted within the scope of this requirement, in line with the research objectives and questions, the inter-variable relationships were first examined and meaningful relationships between meaningful life and psychological resilience, hope, loneliness were determined. Then, as a result of the path analyses proposed by Baron and Kenny (1986) and bootstrapping, the level of hope of university students had a partial mediating effect between meaningful life and psychological resilience; it has also emerged that loneliness levels have a partial mediating effect between meaningful life and psychological resilience.

When the research findings were examined, it was revealed that there was a negatively significant relationship between psychological resilience and loneliness. When the literature is examined, there is a significant negative relationship between loneliness and psychological resilience (Cetin and Anuk, 2020; Guloglu and Kararrmak, 2010; Rew et al., 2001) and findings that loneliness predictpsychological resilience (Altundag, 2013) are consistent with research results. It has been considered that the social support of lonely individuals or feeling alone in public has a negative effect on their psychological resilience. Increased technological possibilities and the entry of social media tools into the lives of individuals have been revealed by researches that make them more lonely (Ando and Sakamoto, 2008; Can and Hovardaoglu, 2015; Dogan and Karakaş, 2016; Pelling and White, 2009; Ryan and Xenos, 
2011; Wilson, Fornasier and White, 2010). These studies point out the reasons for loneliness to occur and the importance of its relationship with psychological resilience. Based on the findings of the research, it is thought that the loneliness levels of the individuals will negatively affect their psychological resilience, also known as resilience.

One of the research findings is that there is a positively significant relationship between psychological resilience and hope. It can be said that the constant hope of individuals positively affects their level of psychological well-being. Supporting this research finding, Karairmak (2007)'s thesis study with individuals who experienced the 1999 earthquake found that psychological resilience and self-respect, hope, optimism, positive emotions and life insatiability are related. The constant search for hope of individuals who experience negative emotions can positively affect their level of psychological resilience and connect them more tightly to life. In other studies conducted with university students, it was determined that individuals with high levels of hope also had high levels of psychological resilience (Snyder, 2000; Kumpfer, 1999) supports the findings of this research.

However, there are some studies in which hope plays a mediating role in the relationship with different variables. In these studies, it was found that hope has an mediating role in the relationship between self-compassion with psychological resilience (Sünbül and Gördesli, 2020) additionally emerged relationship between career and body-sensation goals and career adaptation abilities (Korkmaz and Önder, 2019) and the relationship between acceptance, interest and self-respect perceived from parents (Aydın, Sarı and Şahin, 2012). Research findings show that high levels of hope contribute positively to individuals' psychological well-being and mental health. However, different studies have found that hope predict psychological resilience in neurosurgery (brain and nerve) patients (Duggal, Sacks-Zimmerman and Liberta, 2016), mothers and fathers of children with intellectual disabilities (Lloyd and Hastings, 2009) and older adults (Ong, Edwards and Bergeman, 2006). Hope and psychological resilience is considered to have a protective effect, especially in difficult disease processes such as the Covid-19 pandemic. In one aspect, hope can be considered to have a preparatory effect on future positive events. For this reason, it appears that the effect of hope on the psychological resilience of individuals has become important. The high levels of psychological resilience as a result of individuals' hopefulness confirms the conclusion that there are closely related variables and hope mediates psychological resilience.

Another finding of the study is that meaningful life has a negative relationship with loneliness and a positive relationship with psychological resilience. In addition, in the findings revealed that meaningful life has a partial mediating effect between psychological resilience and loneliness. When the literature is examined, no research examining these findings has been found. This can be considered as an indication that it is an original study in terms of contributing to the literature. When research on meaningful life is examined, emotional balance and meaningful life have an mediating role on the psychological health of young adults (Yildirim, Arslan and Wong, 2020), meaning in life is positively associated with positive emotion and life satisfaction, meaning in life is negatively associated with positive emotion and life satisfaction negative emotions (Dogan et al., 2012; Magno, Galang, Paterno and Roldan, 2011; Santos et al., 2012; Yildirim and Guler 2020). It turns out that individuals with a high sense of meaning in life have more emotional, psychological and social well-being (Damásio, de Melo and da Silva, 2013; García-Alandete et al., 2018; Mulders 2011). As a result of these researches, it is seen that the contribution of researches on meaningful life to psychological health status is positive and in this respect coincides with the finding of relationship between the meaningful life and psychological resilience obtained in the research. The finding that meaningful life is negatively associated with loneliness is consistent with the negative effects of studies on loneliness on psychological health. (Cetin and Anuk, 2020; Guloglu and Kararrmak, 2010; Rew et al., 2001).

\section{Limitations and Suggestions}

When the findings are evaluated, it is seen that meaningful life and hope have a positive effect and loneliness has a negative effect on the high levels of psychological resilience of individuals. It can be said that the loss of expectations for the future and being alone in this process leading to death is the result of low psychological resilience.. It can be said that one way to reduce the negative impact of 
despair and loneliness is for the individual to find their own meaning of life. Starting from here, it may be suggested that specialists who consult psychologically with the individual or group should take into account that meaningful life and hope have a significant impact on the mental health of individuals. In addition, psychoeducationprograms and activities can be carried out to increase the psychological wellbeing of individuals during the Covid 19 pandemic. This research has some limitations.

The research is limited to data collected from four public universities. It is thought that conducting future research with individuals at different universities and in more numbers with sampling may result in different results. A second limitation is that only university students of a certain age range were studied in the study. Future studies can be carried out on individuals of different ages and learning levels.

It is seen that studies on psychological resilience are generally conducted with individuals above the middle socio-economic level. However, studies should be planned on what the factors that affect the psychological resilience levels of low-income individuals and families may be. In this process, he / she can consider the factors that reduce the psychological resilience and plan remedial and protective activities such as psychodrama and parental guidance by the practitioners. In addition, preventive studies can be planned in order not to decrease the level of psychological resilience by considering peer education, cooperation with the school, family background through the effective factors. It will be useful to use qualitative study or mixed (qualitative and quantitative) designs in order to see the testing relationships in different risk groups in more detail.

\section{Disclosure Statements}

Contribution rate statement of researchers: First author \%40, Second author \%35, Third author $\% 25$.

No potential conflict of interest was reported by the authors.

\section{References}

Ahorsu, D. K., Lin, C. Y., Imani, V., Saffari, M., Griffiths, M. D., \& Pakpour, A. H. (2020). The fear of COVID-19 scale: development and initial validation. International Journal Of Mental Health and Addiction, 1-9. https://doi.org/10.1007/s11469-020-00270-8.

Akat, M. \& Karataş, K. (2020). Psychological effects of COVID-19 Pandemic on society and its reflections on education. Turkish Studies, 15(4), 1-13. https://dx.doi.org/10.7827/TurkishStudies.44336.

Aktaş, Y. (1997). Üniversite öğrencilerinin uyum düzeylerinin incelenmesi: Uzunlamasına bir çalışma. Hacettepe Ëniversitesi Ë̈itim Fakültesi Dergisi, 13(13). https://dergipark.org.tr/en/download/article-file/88131.

Altundağ, Y. (2013). Anne babası boşanmış ergenlerin psikolojik dayanıklılık düzeylerinde yordayıcı değişkenler olarak yaşam doyumu ve yalnızlık. (Yayınlanmamış Yüksek Lisans Tezi). Abant İzzet Baysal Üniversitesi Bolu. https://tez.yok.gov.tr/UlusalTezMerkezi/TezGoster?key=1zw6GvYMe-q3Hf6HR3US00A8wYxx339OEfrt7SgW4Qaq1uuOGSqlih z1MocZtz

American Psychological Association. (2020). Keeping your distance to stay safe. Retrieved from https://www.apa.org/practice/programs/dmhi/research-information/social-distancing.

Anderson, J. C., \& Gerbing, D. W. (1988). Structural equation modeling in practice: A review and recommended two-step approach. Psychological bulletin, 103(3), 411-423.

Ando, R., \& Sakamoto, A. (2008). The effect of cyber-friends on loneliness and social anxiety: Differences between high and low self-evaluated physical attractiveness groups. Computers in Human Behavior, 24(3), 993-1009. https://doi.org/10.1016/j.chb.2007.03.003. 
Arden, M. A., \& Chilcot, J. (2020). Health psychology and the coronavirus (COVID-19) global pandemic: A call for research. British Journal of Health Psychology, 1-2. https://doi.org/10.1111/bjhp.12414.

Arslan, G. (2020). Anlamlı yaşam ölçeğinin geliştirilmesi: Anlamlı yaşama ilişkin kısa ve etkili bir ölçme arac1. Mehmet Akif Ersoy Üniversitesi Eğitim Fakültesi Dergisi, (56), 227-242. https://dergipark.org.tr/en/pub/maeuefd/issue/57315/773686.

Arslan, G., \& Allen, K. A. (2020). Complete mental health in elementary school children: Understanding youth school functioning and adjustment. Current Psychology, 1-10. https://doi.org/10.1007/s12144-020-00628-0.

Arslan, G., Yıldırım, M., Karataş, Z., Kabasakal, Z., ve Kılınç, M. (2020). Meaningful living to promote complete mental health among university students in the context of the COVID-19 pandemic. International Journal of Mental Health and Addiction, 1-13. https://doi.org/10.1007/s11469-020-00416-8.

Artan, T., Atak, I., Karaman M. \& Cebeci, F. (2020). Koronavirüs (COVID-19) salgınında sosyodemografik özellikler, psikolojik sağlamlık ve kaygı düzeyleri arasındaki ilişki. Turkish Studies, 15(6), 79-94. http://dx.doi.org/10.7827/TurkishStudies.43882.

Atik, G., \& Atik, Z. E. (2017). Lise öğrencilerinin umut düzeylerinin yordanması: akademik öz-yeterlik ve problem çözmenin rolü. Ĕ̈itim ve Bilim, 42(190).

Aydın, B., Sarı, S. V., \& Şahin, M. (2012). Anne-babadan algılanan kabul/ilgi, benlik saygısı ve akademik başarı: Umudun aracı rolü. Cumhuriyet Uluslararası Eğitim Dergisi, 3(4), 37-48. https://doi.org/10.30703/cije.321356.

Aydın, M., ve Egemberdiyeva, A. (2018). Üniversite öğrencilerinin psikolojik sağlamlık düzeylerinin incelenmesi. Türkiye Eğitim https://dergipark.org.tr/en/pub/turkegitimdergisi/issue/37897/333333.

Bachman, L. F. (2004). Statistical analyses for language assessment book. Cambridge University Press.

Baron, R. M., ve Kenny, D. A. (1986). The moderator-mediator variable distinction in social psychological research: Conceptual, strategic, and statistical considerations. Journal Of Personality and Social Psychology, 51(6), 1173. https://psycnet.apa.org/buy/1987-13085-001.

Berguno, G., Leroux, P., McAinsh, K., ve Shaikh, S. (2004). Children's experience of loneliness at school and its relation to bullying and the quality of teacher interventions. The Qualitative Report, 9 (3), 483-499. http://nsuworks.nova.edu/tqr/vol9/iss3/7.

Beutel, M. E., Klein, E. M., Brähler, E., Reiner, I., Jünger, C., Michal, M., ... \& Tibubos, A. N. (2017). Loneliness in the general population: prevalence, determinants and relations to mental health. BMC psychiatry, 17(1), 97. https://link.springer.com/content/pdf/10.1186/s12888-0171262-x.pdf.

Bilge, Y. \& Bilge, Y. (2020). Koronavirüs salgını ve sosyal izolasyonun psikolojik semptomlar üzerindeki etkilerinin psikolojik sağlamlık ve stresle baş etme tarzları açısından incelenmesi. Klinik Psikiyatri Dergisi, 23(1), 38-51. https://doi.org/10.5505/kpd.2020.66934.

Blazer, D. G. (2002). Self-efficacy and depression in late life: A primary prevention proposal. Aging ve Mental Health, 6 (4), 315-324. https://doi.org/10.1080/1360786021000006938.

Bozdağ, F. (2020). Pandemi sürecinde psikolojik sağlamlık. Electronic Turkish Studies, 15(6). http://dx.doi.org/10.7827/TurkishStudies.44890.

Bu, F., Steptoe, A., \& Fancourt, D. (2020). Who is lonely in lockdown? Cross-cohort analyses of predictors of loneliness before and during the COVID-19 pandemic. Public Health, 186, 31-34. https://doi.org/10.1016/j.puhe.2020.06.036. 
Cai, H., Tu, B., Ma, J., Chen, L., Fu, L., Jiang, Y. \& Zuhang, Q. (2020).Psychological impact and coping strategies of frontline medical staff in Hunan between January and March 2020 during the outbreak of corona virus disease 2019 (covid-19) in Hubei, China. MedSciMonit, 26: e924171. doi: 10.12659/MSM.924171.

Can, F., ve Hovardaoğlu, S. (2015). Romantik ilişkilerde sosyal ağ etkileri. Nesne Psikoloji Dergisi, 3(5). https://www.nesnedergisi.com/makale/pdf/1433593489.pdf.

Çetin, C., ve Anuk, Ö. (2020). Covıd-19 pandemi sürecinde yalnızlık ve psikolojik dayanıklılık: Bir kamu üniversitesi öğrencileri örneklemi. Avrasya Sosyal ve Ekonomi Araştırmaları Dergisi, 7(5), 170-189. https://dergipark.org.tr/en/pub/asead/issue/54658/733121.

Chang, E. C., Sanna, L. J., Hirsch, J. K., ve Jeglic, E. L. (2010). Loneliness and negative life events as predictors of hopelessness and suicidal behaviors in hispanics: Evidence for a diathesis-stress model. Journal of Clinical Psychology, 66 (12), 1242-1253. https://doi.org/10.1002/jclp.20721.

Counted, V., Pargament, K. I., Bechara, A. O., Joynt, S., ve Cowden, R. G. (2020). Hope and well-being in vulnerable contexts during the COVID-19 pandemic: does religious coping matter? The Journal of Positive Psychology, 1-12. https://doi.org/10.1080/17439760.2020.1832247.

Dağc1, A. (2020). Üniversite Öğrencilerinin Dindarlık ve Umut Durumlarının Bazı Değişkenler Açısından İncelenmesi. Türk Din Psikolojisi Dergisi, (2), 9-36. https://dergipark.org.tr/en/pub/tdpd/issue/59126/821240

Damásio, B. F., de Melo, R. L. P., ve da Silva, J. P. (2013). Meaning in life, psychological well-being and quality of life in teachers. Paidéia, 23(54), 73-82. https://doi.org/10.1590/1982$\underline{43272354201309 .}$.

Doğan, T. (2015). Kısa psikolojik sağlamlık ölçeği’nin Türkçe uyarlaması: Geçerlik ve güvenirlik çalışması. The Journal of Happiness ve Well-Being, 3(1), 93-102. https://www.tayfundogan.net/wpcontent/uploads/2016/09/K\%C4\%B1saPsikolojikSaglamlikOlcegi.pdf.

Doğan, T., Sapmaz, F., Tel, F. D., Sapmaz, S., ve Temizel, S. (2012). Meaning in life and subjective well-being among Turkish university students. Procedia Social and Behavioral Sciences, 55, 612-617. https://doi.org/10.1016/j.sbspro.2012.09.543.

Doğan, U., ve Karakaş, Y. (2016). Lise öğrencilerinin sosyal ağ sitleri kullanımının yordayıcısı olarak yalnılık. Sakarya University Journal of Education, 6(1), 57-71. https://doi.org/10.19126/suje.40198.

DuBois, C. M., Lopez, O. V., Beale, E. E., Healy, B. C., Boehm, J. K., ve Huffman, J. C. (2015). Relationships between positive psychological constructs and health outcomes in patients with cardiovascular disease: A systematic review. International Journal of Cardiology, 195, 265-280. https://doi.org/10.1016/j.ijcard.2015.05.121.

Duggal, D., Sacks-Zimmerman, A. ve Liberta, T. (2016) The impact of hope and resilience on multiple factors in neurosurgical patients. Cureus, 8(10): e849. doi: 10.7759/cureus.849.

Emmons, R. A. (2005). Striving for the sacred: Personal goals, life meaning, and religion. Journal of Social Issues, 61(4), 731-745. https://doi.org/10.1111/j.1540-4560.2005.00429.x.

Erkan, S., Özbay, Y., Çankaya, Z. C., \& Terzi, Ş. (2012). Üniversite öğrencilerinin yaşadıkları problemler ve psikolojik yardım arama gönüllükleri. Eğitim ve Bilim,37(164). http://egitimvebilim.ted.org.tr/index.php/EB/article/view/402.

Fardin, M. A. (2020). COVID-19 and anxiety: A review of psychological impacts of infectious disease outbreaks. Archives of Clinical Infectious Diseases, 15(COVID-19). doi: 10.5812/archcid.102779. 
Frankl, V. E. (1985). Man's search for meaning. New York: Simon and Schuster Publishers. http://117.247.251.79:8080/jspui/bitstream/1/1117/1/5.\%20Man\%E2\%80\%99s\%20Search\%20f or\%20Meaning\%20by\%20Viktor\%20E.\%20Frankl.pdf.

Fredrickson, B. L., Tugade, M. M., Waugh, C. E., ve Larkin, G. R. (2003). What good are positive emotions in crisis? A prospective study of resilience and emotions following the terrorist attacks on the United States on September 11th, 2001. Journal of Personality and Social Psychology, 84(2), 365-376. https://www.ncbi.nlm.nih.gov/pmc/articles/PMC2755263/.

García-Alandete, J., Martínez, E. R., Sellés Nohales, P., ve Soucase Lozano, B. (2018). Meaning in life and psychological weil-being in spanish emerging adults. Acta Colombiana de Psicología, 21(1), 196-216. http://dx.doi.org/10.14718/acp.2018.21.1.9.

Gardiner, C., Laud, P., Heaton, T., ve Gott, M. (2020). What is the prevalence of loneliness amongst older people living in residential and nursing care homes? A systematic review and metaanalysis. Age and Ageing, 49 (5), 748-710. https://doi.org/10.1093/ageing/afaa049.

Garrosa-Hernández, E., Carmona-Cobo, I., Ladstätter, F., Blanco, L. M., ve Cooper-Thomas, H. D. (2013). The relationships between family-work interaction, job-related exhaustion, detachment, and meaning in life: A day-level study of emotional well-being. Revista de Psicología del Trabajo $y$ de las Organizaciones, 29(3), 169-177. https://doi.org/10.5093/tr2013a23.

Gizir, C. (2007). Psikolojik sağlamlık, risk faktörleri ve koruyucu faktörler üzerine bir derleme çalışması. Türk Psikolojik Danışma ve Rehberlik Dergisi,3(28), 113-128. https://dergipark.org.tr/en/download/article-file/200204.

Glass, K., Flory, K., Hankin, B. L., Kloos, B., ve Turecki, G. (2009). Are coping strategies, social support, and hope associated with psychological distress among Hurricane Katrina survivors? Journal of Social and Clinical Psychology, 28(6), 779-795. https://doi.org/10.1521/jscp.2009.28.6.779.

Güloğlu, B., ve Karaırmak, Ö. (2010). Üniversite öğrencilerinde yalnızlığın yordayıcısı olarak benlik saygısı ve psikolojik sağlamlı. Ege Eğitim Dergisi, 11(2), 73-88. https://dergipark.org.tr/en/download/article-file/57023.

Hayes, A. F. (2013). An introduction to mediation, moderation, and conditional process analysis. New York: The Guilford Press.

Hayes, A. F. (2013). Introduction to mediation, moderation, and conditional process analysis: A regression-based approach. New York: Guilford Press. http://www.serialssolutions.com/images/AL Button big.gif.

Holmes EA, O'Connor RC, Perry VH, Tracey I, Wessely S, Arseneault L, et al. (2020). Multidisciplinary research priorities for the COVID-19 pandemic: a call for action for mental health science. Lancet Psychiatry. 7(6), 547-560. https://doi.org/10.1016/S2215-0366(20)301681 .

Holt-Lunstad, J. (2017). The potential public health relevance of social isolation and loneliness: Prevalence, epidemiology, and risk factors. The Public Policy and Aging Report, 27, 127-130. https://doi.org/10.1093/ppar/prx030.

Hu, L. T. \& Bentler, P. M. (1999). Cutoff criteria for fit indexes in converiance structure analysis: Conventional criteria versus new alternative Structural Equation Modeling. 6 (1), 1-55.

Huang, Y. ve Zhao, N. (2020). Generalized anxiety disorder, depressive symptoms and sleep quality during COVID 19 epidemic in China: a web-based cross-sectional survey. Psychiatry research, 288, 112954. https://doi.org/10.1016/j.psychres.2020.112954.

Jackson D., Firtko A. ve Edenborough M. (2007) Personal resilience as a strategy for surviving and thriving in the face of workplace adversity: a literature review. Journal of Advanced Nursing, 60(1), 1-9. https://doi.org/10.1111/j.1365-2648.2007.04412.x. 
Jeste D.V., Lee E.E., Cacioppo S. (2020). Battling the modern behavioral epidemic of loneliness: suggestions for research and interventions. JAMA Psychiatry, 77, 553-554. Doi: $10.1001 /$ jamapsychiatry.2020.0027.

Kandemir, F. (2020). Bazı Demografik Değişkenler Bağlamında Covid-19 Pandemi Neslinin Dindarlık ve Ölüm Kaygısı İlişkisi Üzerine Ampirik Bir Araştırma. Tokat Illmiyat Dergisi, 8(1), 99-129. https://doi.org/10.5281/zenodo.3876200

Karairmak, Ö. (2007). Investigation of personal qualities contributing to psychological resilience among earthquake survivors: A model testing study. (Yayımlanmamış doktora tezi). Orta Doğu Teknik Üniversitesi, Ankara. https://hdl.handle.net/11511/17263.

Karairmak, Ö. (2016). Resilience, risk and protective factors. Turkish Psychological Counseling and Guidance Journal, 3(26). http://turkpdrdergisi.com/index.php/pdr/article/view/321.

Karal, E., ve Gül Biçer, B. (2020). Salgın hastalık döneminde algılanan sosyal desteğin bireylerin psikolojik sağlamlığ üzerindeki etkisinin incelenmesi. Birey ve Toplum Sosyal Bilimler Dergisi, 10 (1), 129-156. https://doi.org/10.20493/birtop.726411.

Kardas, F., Zekeriya, C. A. M., Eskisu, M., \& Gelibolu, S. (2019). Gratitude, hope, optimism and life satisfaction as predictors of psychological well-being. Eurasian Journal of Educational Research, 19(82), 81-100. https://dx.doi.org/10.14689/ejer.2019.82.5

Karsi, N. (2020). Üniversite öğrencilerinde hayatin anlami ve dindarlik ilişkisi. OMUIFD: Ondokuz Mayis University Review of the Faculty of Divinity, (48).169-201. https://doi.org/10.17120/omuifd.718108

Kasapoğlu, F. (2020). COVID-19 Salgını Sürecinde Kaygı ile Maneviyat, Psikolojik Sağlamlık ve Belirsizliğe Tahammülsüzlük Arasındaki İlişkilerin İncelenmesi. Electronic Turkish Studies, 15(4). https://dx.doi.org/10.7827/TurkishStudies.44284

Killgore, W. D. S., Cloonan, S. A., Taylor, E. C., \& Dailey, N. S. (2020). Loneliness: A signature mental health concern in the era of COVID-19. Psychiatry Research, 290. https://doi.org/10.1016/j.psychres.2020.113117

Kleftaras, G., ve Psarra, E. (2012). Meaning in life, psychological well-being and depressive symptomatology: A comparative study. Psychology, 3(04), 337. doi: 10.4236/psych.2012.34048.

Kline, R. B. (2015). Principles and practice of structural equation modeling. Yapısal eşitlik modellemesinin ilkeleri ve uygulamasi. (Aydın, B., Atalmış, E.H, Yürekli, H., Yıldırım İ., Akbay, L., Kaplan, M., Yıldırım, M., Baloğlu, M., Terzi, R., Şen, S., Gürel, S., Toker. T., Çev.) Nobel Akademik Yayıncılık.

Kluge, H. P. (2020). Statement - physical and mental health key to resilience during COVID-19 pandemic. World Health Organization. https://www.euro.who.int/en/mediacentre/sections/statements/2020/statement-physical-and-mental-health-key-to-resilience-duringcovid-19-pandemic.

Korkmaz, O., \& Önder, F. C. (2019). Yaşam amaçları ile kariyer uyum yetenekleri arasındaki ilişki: umudun aracilık rolünün incelenmesi. Eğitim ve Bilim, 44(200). http://dx.doi.org/10.15390/EB.2019.8380.

Korkut-Owen, F., Demirbaş-Çelik, N., Doğan, T. (2017). Üniversite öğrencilerinde iyilik halinin yordayıcıs1 olarak psikolojik sağlamlık. Electronic Journal of Social Sciences, 16(64). https://doi.org/10.17755/esosder.300405.

Kumpfer, K. L. (1999). Factors and process contributing to resilience: The resilience framework. In M. D. Glantz, ve J. L. Johnson (Eds.), Resilience and development: Positive life adaptations. (pp. 179- 224). New York: Kluwer Academic/ Plennum Publishers. 
Lau, J.T., Wang, Z., Kim, Y., Gu, J., Wu, A.M., Zhou, Q., ... Hao, Y. (2016). Anticipated negative responses by students to possible Ebola virus outbreak, Guangzhou China. Emerging Infectious Diseases, 22(1), 154- 156. doi: 10.3201/eid2201.150898.

Lee, S.M., Kang, W.S., Cho, A.-R., Kim, T., ve Park, J.K. (2018). Psychological impact of the 2015 MERS outbreak on hospital workers and quarantined hemodialysis patients. Comprehensive Psychiatry, 87, 123-127. https://doi.org/10.1016/j.comppsych.2018.10.003.

Li, L. Z., ve Wang, S. (2020). Prevalence and predictors of general psychiatric disorders and loneliness during COVID-19 in the United Kingdom. Psychiatry Research, 291. https://doi.org/10.1016/j.psychres.2020.113267.

Lin, C. Y. (2020). Social reaction toward the 2019 novel coronavirus (COVID-19). Social Health and Behavior, 3(1), 1. https://www.shbonweb.com/text.asp?2020/3/1/1/280554.

Lin, J., Ren, Y., Gan, H., Chen, Y., Huang, Y., ve You, X., (2020). Factors influencing resilience of medical workers from other provinces to Wuhan fighting against 2019 novel coronavirus pneumonia. BMC Psychiatry, 1-15. Doi: 10.21203/rs.3.rs-17931/v1.

Lloyd, J. T. ve Hastings, R. (2006). Hope as a psychological resilience factor in mothers and fathers of children with intellectual disabilities. Journal of Intellectual Disability Research, 53(12), 957968. https://doi.org/10.1111/j.1365-2788.2009.01206.x.

Maccallum, F., ve Bryant, R. A. (2020). A network approach to understanding quality of life impairments in prolonged grief disorder. Journal of Traumatic Stress,33(1), 106-115. https://doi.org/10.1002/jts.22383.

Magno, C., Galang, M. J. A., Paterno, V. C., ve Roldan, A. E. (2011). Meaning in life, flow, and subjective well-being: a perspective on Filipino High School Students. Philippine Journal of Counseling Psychology, 13(1), 1-1. https://ejournals.ph/article.php?id=6802.

Mascaro, N., ve Rosen, D. H. (2005). Existential meaning's role in the enhancement of hope and prevention of depressive symptoms. Journal of Personality, 73(4), 985-1014. https://doi.org/10.1111/j.1467-6494.2005.00336.x.

Mertens, G., Gerritsen, L., Duijndam, S., Salemink, E., ve Engelhard, I. M. (2020). Fear of the coronavirus (COVID-19): Predictors in an online study conducted in March 2020. Journal of Anxiety Disorders, 74. https://doi.org/10.1016/j.janxdis.2020.102258.

Miller-Smedema, S., Catalano, D., ve Ebener, D. J. (2010). The relationship of coping, self-worth, and subjective well-being: A structural equation model. Rehabilitation Counseling Bulletin, 53(3), 131-142. https://doi.org/10.1177/0034355209358272.

Minkkinen, J., Auvinen, E., \& Mauno, S. (2020). Meaningful work protects teachers' self-rated health under stressors. Journal of Positive School Psychology, 4(2), 140-152. https://doi.org/10.47602/jpsp.v4i2.209.

Mulders, L. T. E. (2011). Meaning in life and its relationship to psychological well-being in adolescents (Master's thesis). https://dspace.library.uu.nl/handle/1874/202850.

Naeem, F., Irfan, M. ve Javed, A. (2020). Copingwith COVID-19: urgent need for building resilience through cognitive behaviour therapy. Khyber MedUniv Journal, 12(1), 1-3. https://doi.org/10.35845/kmuj.2020.20194.

Ong, A. D., Edwards, L. M., ve Bergeman, C. S. (2006). Hope as a source of resilience in later adulthood. Personality and individual differences, 41(7), 1263-1273. https://doi.org/10.1016/j.paid.2006.03.028.

Öz, F., ve Bahadır Yılmaz, E. (2009). Ruh sağlı̆̆ının korunmasında önemli bir kavram: Psikolojik sağlamlı. Hacettepe Üniversitesi Hemşirelik Fakültesi Dergisi, 16(3), 82-89. https://dergipark.org.tr/en/pub/hunhemsire/issue/7841/103278. 
Pelling, E. L., \& White, K. M. (2009). The theory of planned behavior applied to young people's use of social networking web sites. CyberPsychology \& Behavior, 12(6), 755-759. https://doi.org/10.1089/cpb.2009.0109.

Peplau, L.A., Perlman, D. (1982). Perspectives

on loneliness. In L. A.Peplau ve D.Perlman (Eds.), Loneliness: A sourcebook of current theory, research, and therapy (pp. 1-18). John Wiley.

Preacher, K. J., \& Hayes, A. F. (2008). Asymptotic and resampling strategies for assessing and comparing indirect effects in multiple mediator models. Behavior research methods, 40(3), 879891.

Preacher, K. J., ve Hayes, A. F. (2004). SPSS and SAS procedures for estimating indirect effects in simple mediation models. Behavior research methods, instruments, ve computers, 36(4), 717731. https://doi.org/10.3758/BF03206553.

Preacher, K. J., ve Hayes, A. F. (2008). Asymptotic and resampling strategies for assessing and comparing indirect effects in multiple mediator models. Behavior research methods, 40(3), 879891. https://doi.org/10.3758/BRM.40.3.879.

Qiu, J., Shen, B., Zhao, M., Wang, Z., Xie, B., ve Xu, Y. (2020). A nationwide survey of psychological distress among Chinese people in the COVID-19 epidemic: implications and policy recommendations. General psychiatry, 33(2). doi: 10.1136/gpsych-2020-100213.

Rawdin, B., Evans, C., ve Rabow, M. W. (2013). The relationships among hope, pain, psychological distress, and spiritual well-being in oncology outpatients. Journal of Palliative Medicine, 16(2), 167-172. https://doi.org/10.1089/jpm.2012.0223.

Rew, L., Taylor-Seehafer, M., Thomas, N. Y. ve Yockey, R. D. (2001). Correlates of resilience in homeless adolescents. Journal of Nursing Scholarship, 33(1), 33-40. https://doi.org/10.1111/j.1547-5069.2001.00033.x.

Russell, D., Peplau, L. A., ve Ferguson, M. L. (1978). Developing a measure of loneliness. Journal of personality assessment, 42(3), 290-294. https://doi.org/10.1207/s15327752jpa4203_11.

Ryan, T., ve Xenos, S. (2011). Who Uses Facebook? An Investigation into the Relationship between the Big Five, Shyness, Narcissism, Loneliness, and Facebook Usage. Computers in Human Behavior, 27(5), 1658-1664. https://doi.org/10.1016/j.chb.2011.02.004.

Santos, M. C. J., Magramo Jr, C., Oguan Jr, F., Paat, J. J., ve Barnachea, E. A. (2012). Meaning in life and subjective well-being: is a satisfying life meaningful? Researchers World, 3(4), 32. http://www.researchersworld.com/vol3/issue4/vol3_issue4_1/Paper_05.pdf.

Satici, S.A., Kayis, A.R., Satici, B. et al. Resilience, Hope, and Subjective Happiness Among the Turkish Population: Fear of COVID-19 as a Mediator. Int J Ment Health Addiction (2020). https://doi.org/10.1007/s11469-020-00443-5.

Schwarzer, R., ve Luszczynska, A. (2008). Reactive, anticipatory, preventive and proactive coping: A theoretical distinction. The Prevention Researcher, 15(4), 22-24. http://www.tpronline.org/product_toc/15-4-toc.pdf.

Sharf, R. S. (2012). Theories of psychotherapy ve counseling: concepts and cases. (5th Ed.). USA: Brooks/Cole.

Smith, B. W., Dalen, J., Wiggins, K., Tooley, E., Christopher, P., ve Bernard, J. (2008). The brief resilience scale: Assessing the ability to bounce back. International Journal of Behavioral Medicine, 15, 194-200. https://doi.org/10.1080/10705500802222972.

Snyder, C. R. (2000). The past and possible futures of hope. Journal of Social and Clinical Psychology, 19, 11-28. https://doi.org/10.1521/jscp.2000.19.1.11.

Snyder, C. R., Harris, C., Anderson, J. R., Holleran, S. A., Irving, L. M., Sigmon, S. T., ... ve Harney, P. (1991). The will and the ways: development and validation of an individual-differences 
measure of hope. Journal of personality and social psychology,60(4), 570. https://doi.org/10.1037/0022-3514.60.4.570.

Stankovska, G., Memedi, I., ve Dimitrovski, D. (2020). Coronavırus COVID-19 disease, mental health and psychosocial support. Society Register, 4(2), 33-48. https://doi.org/10.14746/sr.2020.4.2.03.

Sünbül, Z. A., ve Gördesli, M. A. (2020). Self-compassion and resilience in parents of children with special needs: The mediating role of hope. Çukurova Üniversitesi Eğitim Fakültesi Dergisi, 49(2), 690-705. https://dergipark.org.tr/en/pub/cuefd/issue/57389/749645.

Tabachnick, B. G., \& Fidell, L. S. (2012). Using Multivariate Statistics (6th. Ed.). New Jersey: Pearson Education.

Tanhan, A., Yavuz, K. F., Young, J. S., Nalbant, A., Arslan, G., Yıldırım, M. ... Çiçek, İ. (2020). A proposed framework based on literature review of online contextual mental health services to enhance wellbeing and address psychopathology during covid-19. Electronic Journal of General Medicine, 17(6). https://dx.doi.org/10.29333/ejgm/8316.

Tarhan, S., ve Bacanlı, H. (2015). Sürekli Umut Ölçeği'nin Türkçe’ye uyarlanması: Geçerlik ve güvenirlik çalışması. The Journal of Happiness ve Well-Being, 3(1), 1-14. https://www.journalofhappiness.net/article/surekli-umut-olceginin-turkceye-uyarlanmasigecerlik-ve-guvenirlik-calismasi.

Tusaie, K., ve Dyer, J. (2004). Resilience: A historical review of the construct. Holistic nursing practice, 18(1), 3-10. Doi: 10.1097/00004650-200401000-00002.

Walsh, F. (2020). Loss and resilience in the time of COVID-19: Meaning making, hope, and transcendence. Family process, 59(3), 898-911. https://doi.org/10.1111/famp.12588.

Wang, C., Pan, R., Wan, X., Tan, Y., Xu, L., Ho, C. S., ve Ho, R. C. (2020). Immediate psychological responses and associated factors during the initial stage of the 2019 coronavirus disease (COVID19) epidemic among the general population in China. International Journal of Environmental Research and Public Health, 17(5), 1729. doi: 10.3390/ijerph17051729.

Wanng, J., \& Wang, X. (2012). Structural equation modeling: Applications using Mplus. WestSussex, UK: John Wiley \& Sons.

Waynor, W. R., Gao, N., Dolce, J. N., Haytas, L. A., \& Reilly, A. (2012). The relationship between hope and symptoms. Psychiatric Rehabilitation Journal, 35(4), 345-348. https://doi.org/10.2975/35.4.2012.345.348.

Weingarten, K. (2010). Reasonable hope: Construct, clinical applications, and supports. Family Process, 49, 5-25. https://doi.org/10.1111/j.1545-5300.2010.01305.x.

Wilson, K., Fornasier, S., \& White, K. M. (2010). Psychological predictors of young adults' use of social networking sites. Cyberpsychology, behavior, and social networking, 13(2), 173-177. https://doi.org/10.1089/cyber.2009.0094.

Yildirim, İ. (2000). Akademik başarını yordayıcısı olarak yalnızlık sınav kaygısı ve sosyal destek. Hacettepe Üniversitesi Eğitim Fakültesi Dergisi, 18(18). https://dergipark.org.tr/en/download/article-file/88017.

Y1ldırım, M., Arslan, G., ve Wong, P. T. (2020). Meaningful living, resilience, affective balance, and psychological health problems among Turkish young adults during coronavirus pandemic. Current Psychology, 1-12. https://doi.org/10.1007/s12144-020-01244-8.

Y1ldirım, M., ve Arslan, G. (2020). Exploring the associations between resilience, dispositional hope, preventive behaviours, subjective well-being, and psychological health among adults during early stage of COVID-19. Current Psychology, 1-11. https://doi.org/10.1007/s12144-020-01177-2. 
Yıldırım, M., ve Güler, A. (2020). Positivity explains how COVID-19 perceived risk increases death distress and reduces happiness. Personality and Individual Differences, 168, 110347. https://doi.org/10.1016/j.paid.2020.110347.

Yıldız, M. A., ve Duy, B. (2014). Adaptation of the short-form of the UCLA loneliness scale (ULS-8) to Turkish for the adolescents. Düşünen Adam, 27(3), 194. https://dx.doi.org/10.5350/DAJPN2014270302. 